\title{
Experimental analysis of solar distillation unit with various slope angles
}

\author{
S. Irfan Sadaq ${ }^{1 *}$ and Syed Nawazish Mehdi ${ }^{2}$ \\ Research Scholar, Department of Mechanical Engineering, Mewar University, Rajasthan, India ${ }^{1}$ \\ Research Supervisor, Department of Mechanical Engineering, Mewar University, Rajasthan, India ${ }^{2}$
}

C2018 ACCENTS

\begin{abstract}
Demand on fresh water usage for agricultural, industrial and domestic purpose is increasing both in urban and rural areas. This is because of everlasting increase in population. The major health issue in these areas has created a challenge to the mankind. Now there is a need to develop a new device which fulfills the health issue. The present work aims in evaluating the performance of solar distillation unit (i.e. Solar Still) with various slope angles at Hyderabad latitude (at Sultan Ul Uloom Education Society Campus, Hyderabad). Experimentation work is carried on the fabricated solar distillation unit with slope angles under different climatical condition from January starting day to the last day of June. Using solar calculations radiation on these days is calculated. The efficiency of solar still and energy is obtained from the amount of water collected from the still throughout the day from10:00AM to 04:00PM, was observed to be around 12\% high with $35^{\circ}$ slope angle for desalination of samples of ocean water.
\end{abstract}

\section{Keywords}

Solar radiation, Solar distillation unit (SDU), Slope angle, Water temperature, Energy, Efficiency.

\section{Introduction}

Nature's gift i.e. water plays an important role in developing and under developing countries. Major problems now a day facing whole world is availability of fresh water for drinking [1]. In the polar region $2 \%$ of water is available in fresh form and $1 \%$ is being used by humans, plants and animals in their daily life and remaining is in the form of salt water (i.e. Ocean water) [2]. Major health issues are caused due to water contamination. Due to insufficient rain fall salinity water increased rapidly in major parts of the world. The possession of polluting water increases drastically due to increase in population and increase in industrialization, which results affecting the agriculture in rural areas and availability of unreliable fresh water in urban areas. Increase in desertification and drought in worldwide results in shortage of fresh drinking water which is now a biggest problem in the world [3].

Current growth in increase in population which may reach up to 800 crores by 2025 (Prediction), reduces water per capita. Two third of population may receive contaminant water due to pollution and exhaustion of water supply by the end of 2025[4]. Most of the females spend their time in collection of water.

*Author for correspondence

172
Due to untreated water around 3.575 millions of people die in the world due to contamination of water which causes major health issues in rural areas [5].

The best solution to overcome the health issue in rural is water purification using desalination. Solar distillation is one of the best method in rural areas, as solar energy is abundantly available in rural areas [6]. Hydrological cycle i.e. evaporation and condensation process is one of the economical technology which can be used both in rural areas and urban areas all over the world for purification water using solar distillation unit (SDU) [7, 8].

Basic principle involved in SDU / still is evaporation and condensation. The polluted water in the SDU is first heated by solar radiation which passes through the top cover and causes evaporation. Difference between the glass cover and water leads to condense water leaving contamination in still.

\section{Solar distillation}

Earth surface is covers about $77 \%$ of water, most of them are either in ice bergs or sea water located at Polar Regions. Water available in form of salty water, and less quantity of fresh form of water which is $>1 \%$ what is being used by living beings now a days. The problem of purification of water can be solved by using hydrological cycle. Distillation of 
sea / ocean water is one of the most prominent processes used for water purification. Most commercially used is solar still. The efficiency of a solar still is based on the amount of water distilled from the still. The source of energy available is a non-consumable and free, nevertheless irregular in availability. The energy varies time to time throughout the day based on the climatic conditions. For high efficiency the solar still must be keep a high temperature of water feed into it, which absorbs feed water as heat by incoming radiation Water plays an important role in developing the economy of the country and its welfare of the nation. Unavailability of the water is one of the major problems facing by the many undeveloped countries over the world. Today, majority of the health issues are due to contaminate drinking water. The effluence of water re- sources is growing significantly suitably to a number of factors together with growth in the population, urbanization, industrialization, etc. This behavior unfavorably affects the quality of water in rural areas.

Basic principle of solar still is evaporation and condensation. The mixed saline water is poured into solar still and sun rays pierces a glass surface sourcing the water get heated. When water gets evaporated inside the solar still, it leaves all contaminants in water down the basin. After evaporation the water now gets purified, condensed below the glass and runs into a collector.

\section{Literature survey}

Computational fluid dynamics (CFD) analysis is carried out by modeling the conventional solar still [9]. The results of experimental study are compared by CFD. Solar still is low cost, reliable used for domestic purpose. Evaporation and condensation is basic principle in distillation process. Later properties of water measured to make the evident from normal to distilled water. Temperature distribution is carried on the glass cover were later verified by using dynamic approach using ANSYS.

Performance of solar still by using absorbing material are carried [10]. Solar still is simple device used to convert saline water to fresh water. Due to low distillation output it is not performable in house hold applications. Based on the absorbing capacity of material and heat of the sun at peaks increases the output of distilled water. Modeling of fluid flow over the solar still and temperature distribution across the still is carried out [11], by using CFD analysis to determine the velocity, shear stress distribution and heat transfer coefficient. Flow circulation across the still is increases with the increase in the yield of the device.

Numerical three-dimensional flow in a collector with baffles is studied by considering the fluid flow and heat transfer collector by using CFD [12]. CFD tool Fluent and CFX has been used to simulate the solar collector for superior understanding of the heat transfer facility. Later theoretically and experimentally work done using CFD tool are compared with respect to flow and temperature distribution inside the solar collector. CFD analysis of single and double basin solar still is carried out using solid works and ANSYS [13], to determine the maximum production rate and distribution across the still.

The supply of fresh water being used by human being to meet their daily demands both in industrial and house hold application is the major issues across the Arabian countries because of water scarcity. Water available is less than one percent. Experimental and CFD simulation is conducted to determine the rate of water production using solar still [14]. Finally $0.47 \mathrm{~kg} / \mathrm{m}^{2} . \mathrm{hr}$ fresh water was produced using preheated tap water which results in 57\% increase in the production using pyramid shape still compare with single slope solar still and also $27 \%$ increase in inclined solar still. The CFD simulation predictions and the experimental results are agreeable with a percentage deviation ranging from $7.8 \%-15.7 \%$ by comparing the rate of fresh water production from both types of analysis. Performance of solar still coated with granular activated carbon is evaluated [15] by using solar pond pre-heated water supplied to still with a depth of $0.01 \mathrm{~m}$. Using Matlab simulation results were obtained. Experimental Investigation on a Thermal Model for a Basin type Solar Still with a peripheral reflector studied [16]. To estimating the efficiency of a basin, the energy balance equations of singular parts of the solar still were used. Accuracy of the SDU with an external reflector was raised by conducting various experiments. Amount of distilled water on hourly basics at different places of the still were calculated using the thermal model and compared with experimental measurements. Therefore, it may conclude with the intention that the efficiency of the basin solar still with an external reflector was enhanced to $44 \%$ in the afternoon. Additionally, it has been concluded that the collected distilled water was about $4600 \mathrm{ml} /$ day and 4300 $\mathrm{ml} /$ day for the examination conducted both by theoretical and experimental. 


\section{Fabrication and testing of solar still 4.1Working of solar still}

SDU known as stills is used for purification of water. The principle of rainwater is the main example how the SDU works. Solar stills mimic this natural process. A solar still as shown in figure 1has a top cover made of glass, with an interior surface made of a waterproof membrane. The interior surface of still is coated with black color to improve distillation. The water in SDU gets heated and evaporates and condensed due to difference in temperature. Water collected on hourly basis is measured throughout the day.

\subsection{Fabrication of solar distillation unit (SDU)}

Typical solar distillation unit, i.e., solar still consists of wooden box and aluminum sheet tray. Top of the still is covered by glass in order to increase the solar intensity. Thickness of the aluminum sheet is $3 \mathrm{~mm}$ and thickness of glass is $5 \mathrm{~mm}$. front wall of the still is $18 \mathrm{~cm}$ in height and length is $54 \mathrm{~cm}$. the back wall of the still is $56 \mathrm{~cm}$ in height making an angle of $35^{\circ}$ to the front wall. Wood thickness is $2.5 \mathrm{~cm}$ and it is used to minimize heat loss from the system. Evaporation and condensation is the process taking place. Salt water is filled in the system using the inlet PVC pipe of 1inch and allowed to get evaporated in sunlight. Temperature of inside water, outlet water and glass are measured at one hour once. Optimum evaporation is achieved at noon. Water vapor gets condensed in glass cover. Provision is made to collect the condensed distilled water and the condensed water can be collected with the help of outlet pipe. Experiment is carried out from 10.00 A.M to 4.00 P.M with time interval of one hour. Experiment setup solid model is shown in Figure 1. Experiment is carried out in college campus in the month of Feb'18 to June'18.

The temperature of the glass, aluminum sheet, water and temperature inside the still is noted down on every hour once from $10 \mathrm{am}$ to $4 \mathrm{pm}$. The temperature is noted with the help of thermo couples which are attached to the glass aluminum sheet and dipped in water and air gap temperature by putting the thermocouples inside the still. And with help of temperature indicator the temperature can be seen and noted down of the months February to June middle and end of every month temperatures are noted from $10 \mathrm{am}$ to $4 \mathrm{pm}$. On hourly once the temperatures are noted down.
The solar still is made up wooden box containing of aluminum sheet of $0.2 \mathrm{~cm}$ inside it. The thickness of the wooden box is $2.5 \mathrm{~cm}$ and there is glass on the top of the solar still with the thickness of $0.5 \mathrm{~cm}$, which are connected of inlet pipe where the salt / impure water can pour inside the still. The front wall length is $54 \mathrm{~cm}$ and the height is $18 \mathrm{~cm}$ and the back wall height is $56 \mathrm{~cm}$ and length is $54 \mathrm{~cm}$. from the back wall to the front wall the solar still is inclined at an angle of $35^{\circ}$ and $30^{\circ}$ as shown in Figure 2

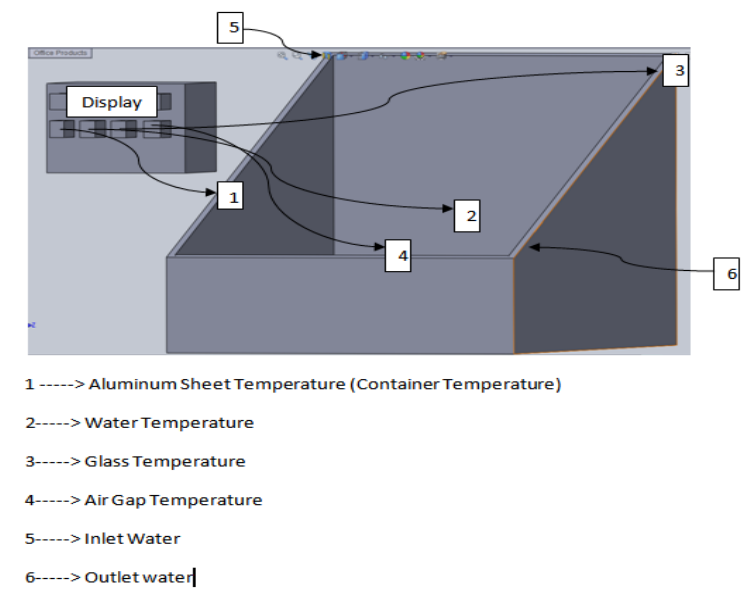

Figure 1 Solid model of SDU / still

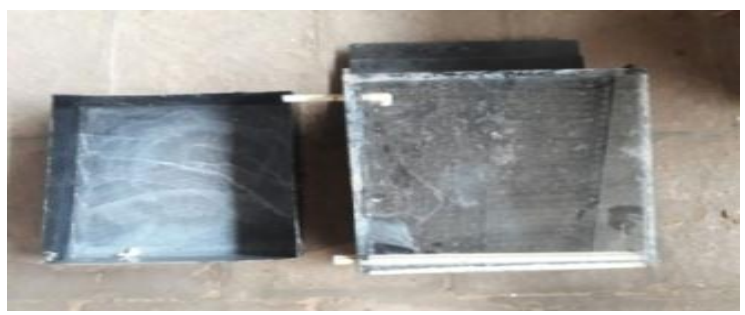

Figure 2 SDU / still setup

In the above Figure 3 thermocouples connected to the solar still. Four k-type thermocouple are used in a still. Thermocouple $T_{1}$ is attached to Aluminum sheet and thermocouple $\mathrm{T}_{2}$ is dipped in Water thermocouple $\mathrm{T}_{3}$ is connected to Glass and Thermocouple $\mathrm{T}_{4}$ is put inside the Air Gap of Solar Still.

All the four thermocouple are connected to the temperature indicator as shown in Figure 4. The multimeter at a time and temperature can be noted just by changing the channel of the indicator and each temperature is noted separately. 


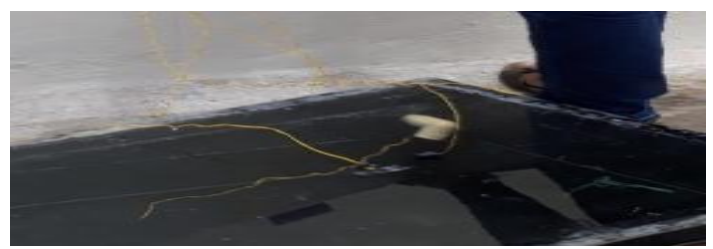

Figure 3 Thermocouple connected to SDU

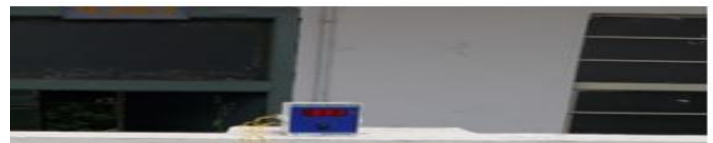

Figure 4 Temperature indicator (multimeter)

The condensation of water takes in form of droplets when the temperature increases as shown in Figure 5. And the droplets goes down from the glass and it when on the half cut pipe which is fixed inside and attached to the front wall and it is collected into the container. In Figure 6 the inlet and outlet pipe can be seen the pipe used is PVC pipe of linch diameter. The inlet pipe used for putting the salt water inside solar still and the outlet pipe is used to collect the pure condensed water as shown in Figure 7.

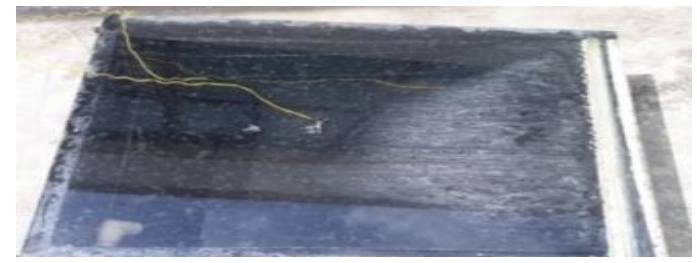

Figure 5 Condensation of water

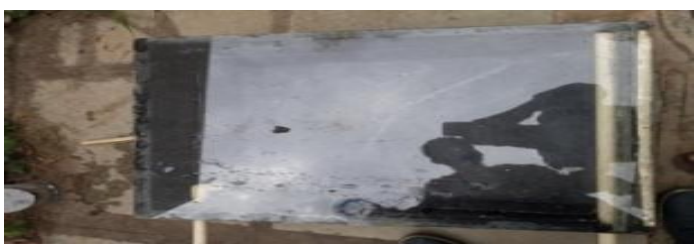

Figure 6 Inlet and Outlet pipe

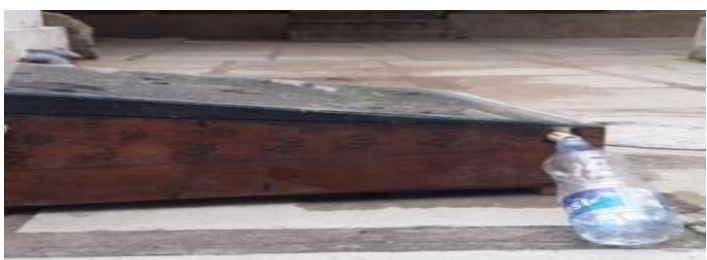

Figure 7 Collection of water from the SDU / still through the outlet pipe

\section{Results and discussion}

An experiment is conducted on SDU is carried out for different slopes angles (i.e. $35^{\circ} \& 30^{\circ}$ ), different time period of the day i.e. 10 am to $4 \mathrm{pm}$ at Hyderabad latitude (SUES Campus). Solar still made with wooden block, aluminum container, glass cover. The experiment was conducted on two different days of each month (i.e. middle date of the month and ending date of the month) starting from February'18 to June'18. The results obtained by this experimentation are tabulated in Tables $1(a \& b)$ and the corresponding graphs are plotted and are shown in Figures 8 to 17. Corresponding energy obtained and efficiency is shown in Figures 18 to 20.

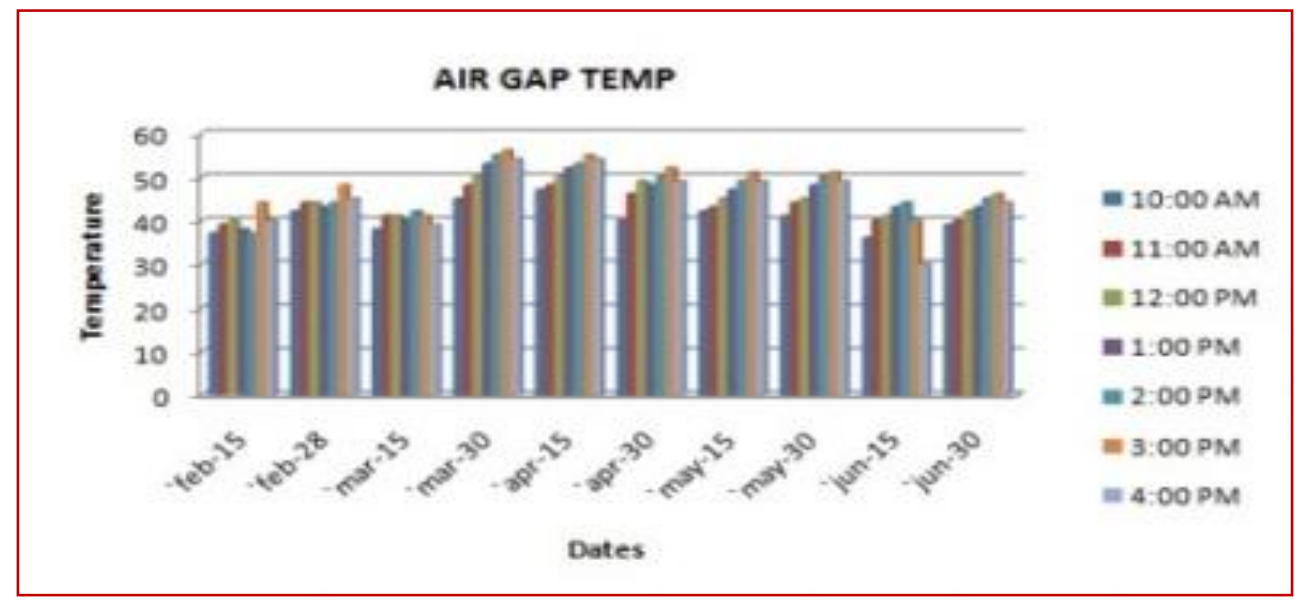

Figure 8 Graph represents the evaporated water temperature at different time interval on different days with slope angle $35^{\circ}$ with respect to the horizontal ground surface 


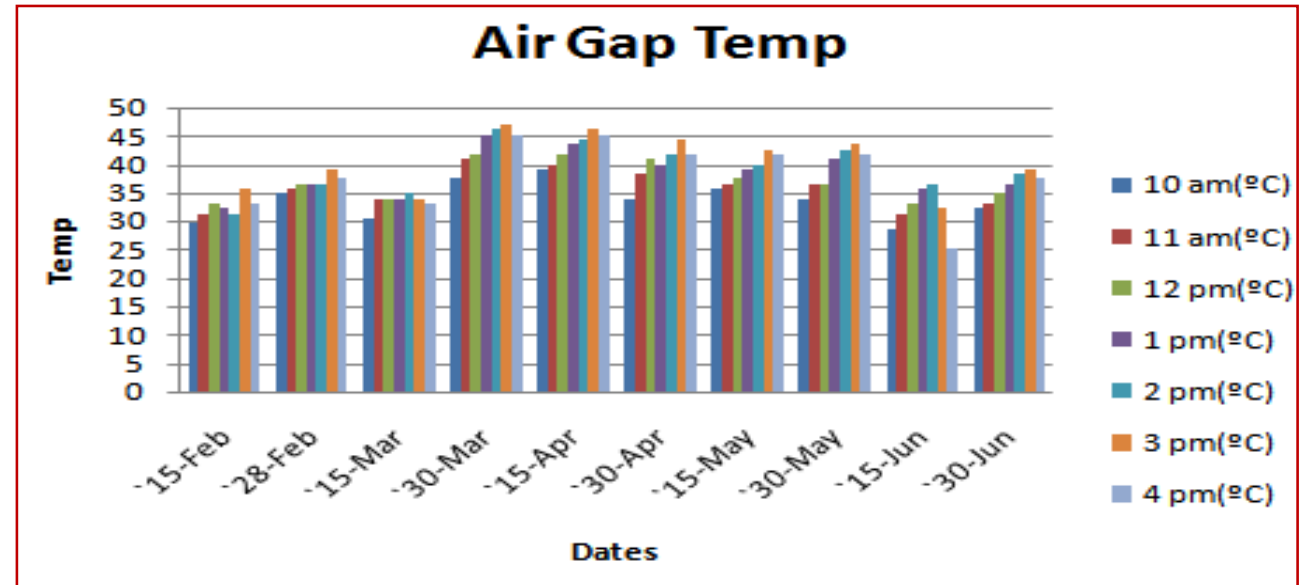

Figure 9 Graph represents the evaporated water temperature at different time interval on different days with slope angle $30^{\circ}$ with respect to the horizontal ground surface

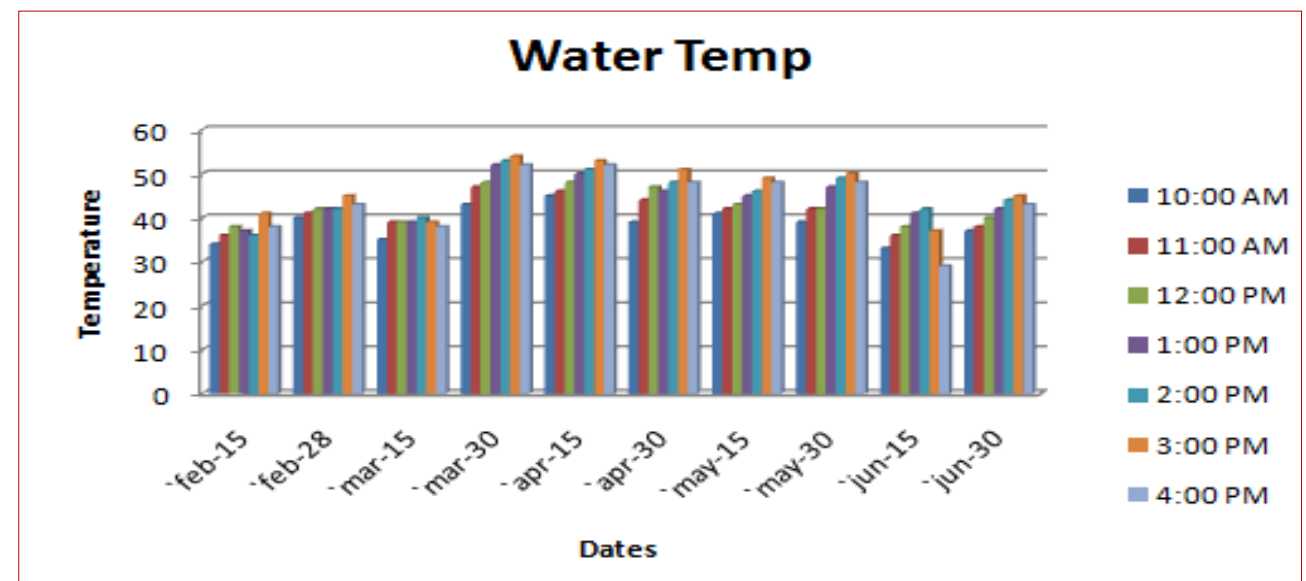

Figure 10 Graph represents the water temperature inside the container at different time interval on different days with slope angle $35^{\circ}$ with respect to the horizontal ground surface

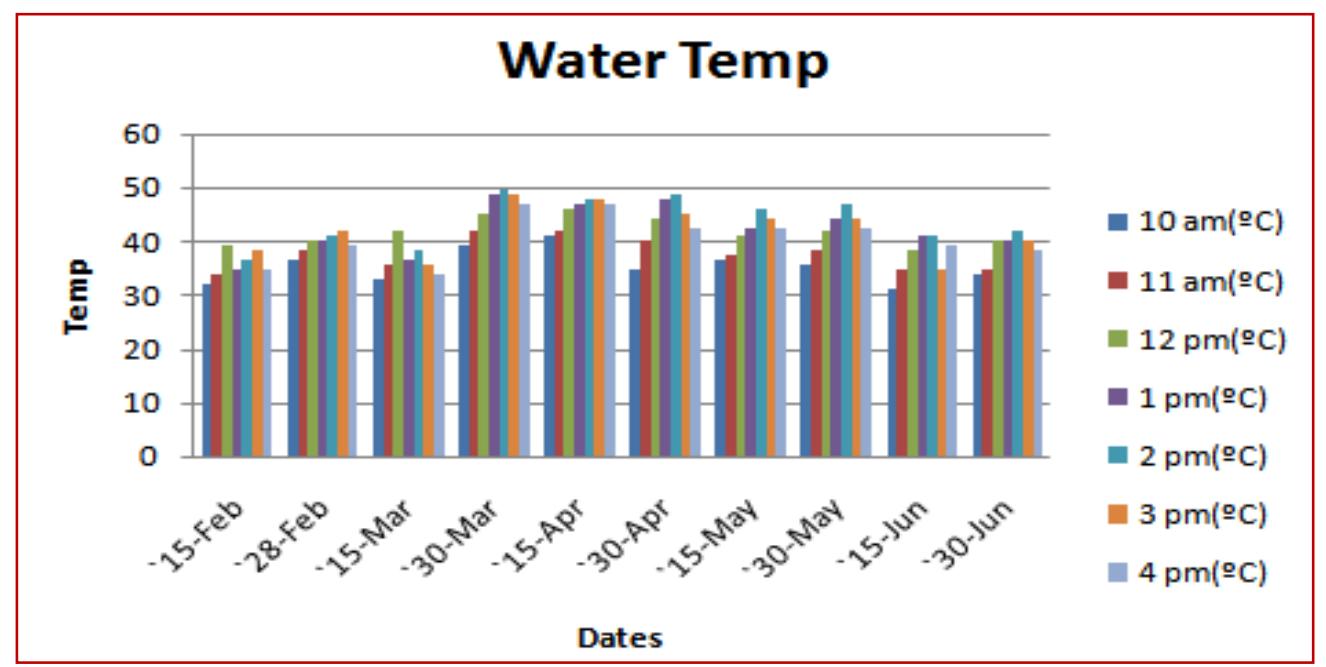

Figure 11 Graph represents the water temperature inside the container at different time interval on different days with slope angle $30^{\circ}$ with respect to the horizontal ground surface 


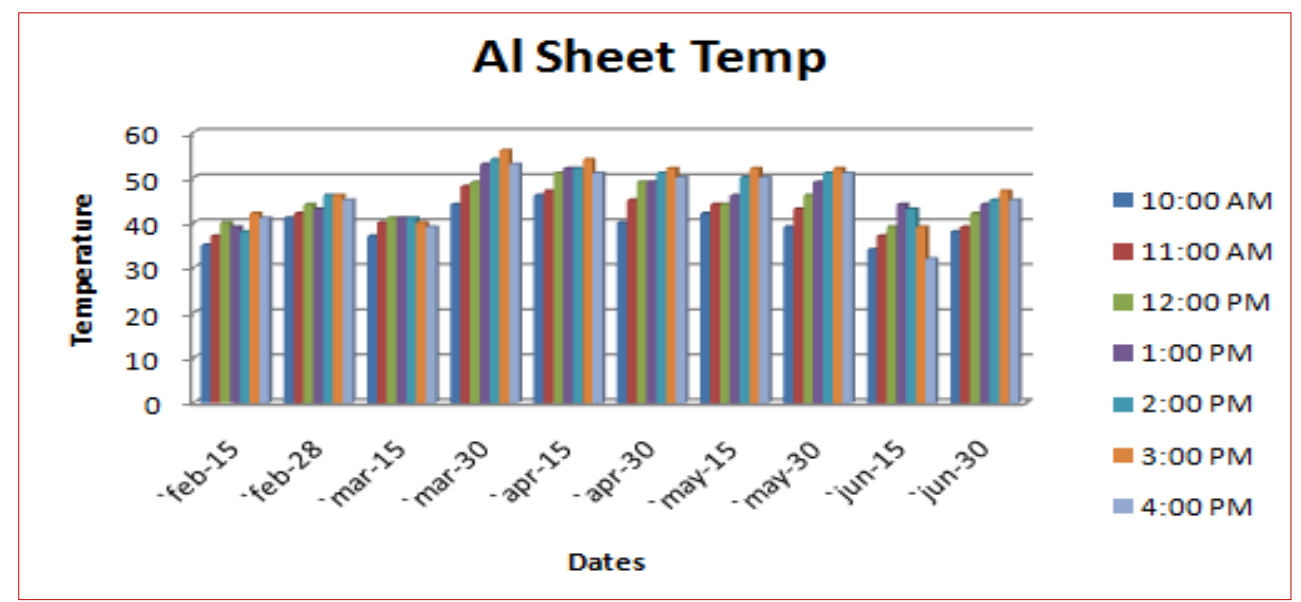

Figure 12 Graph represents the Al Sheet container temperature at different time interval on different days with slope angle $35^{\circ}$ with respect to the horizontal ground surface

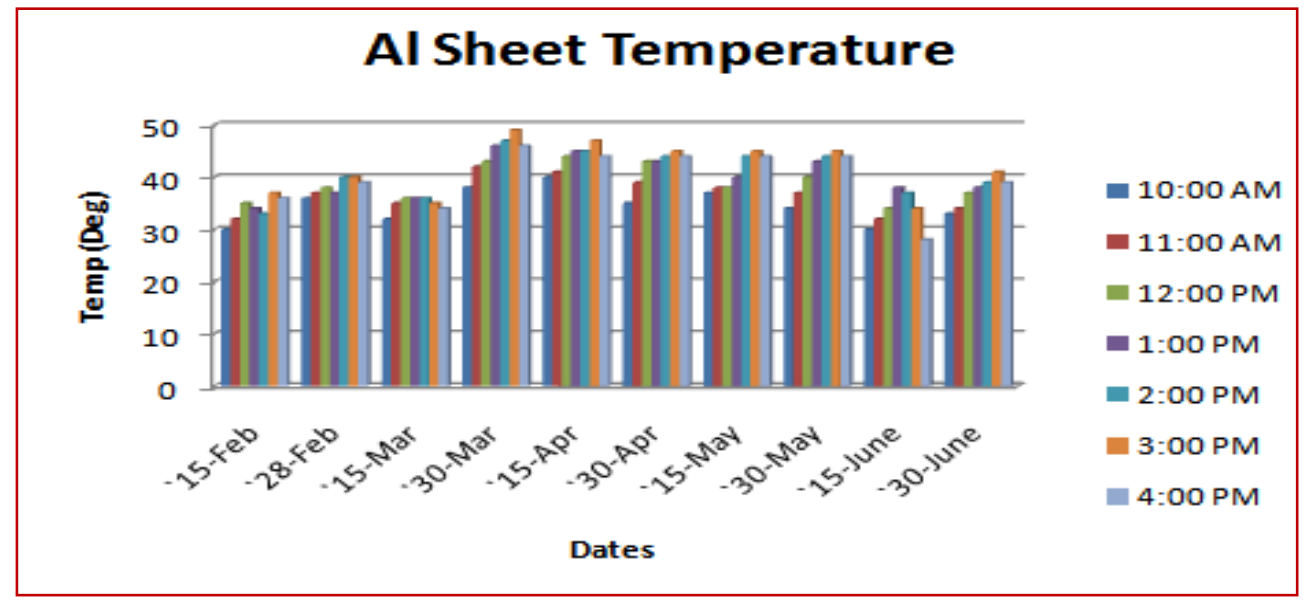

Figure 13 Graph represents the Al Sheet container temperature at different time interval on different days with slope angle $30^{\circ}$ with respect to the horizontal ground surface

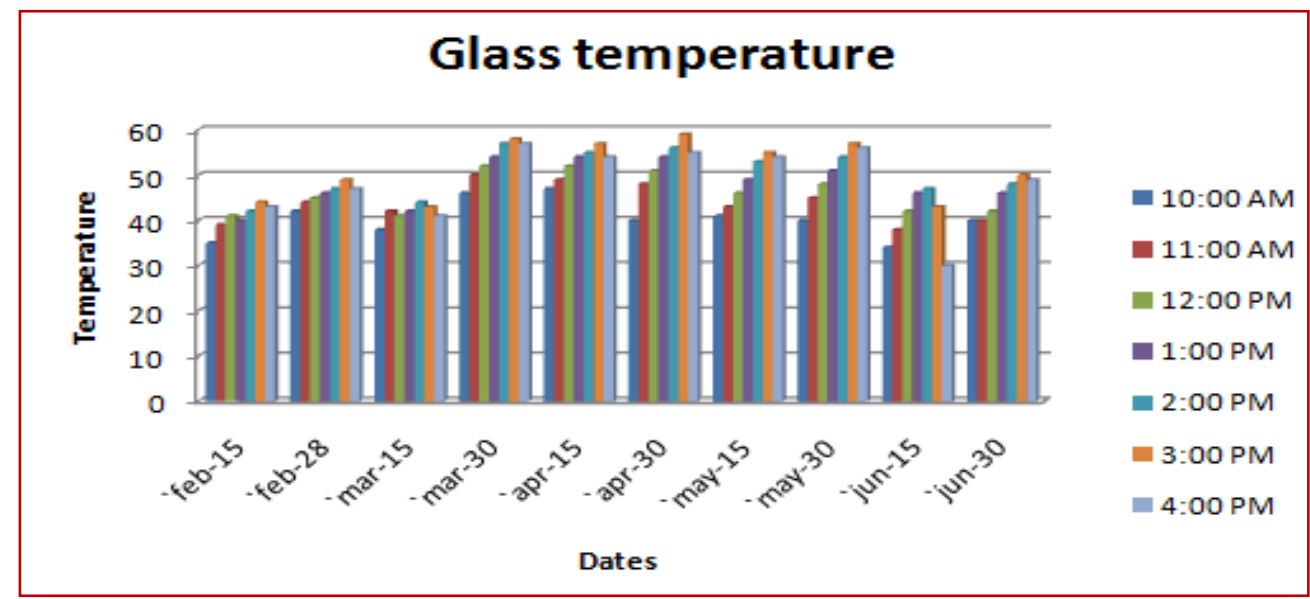

Figure 14 Graph represents the condensed glass temperature at different time interval on different days with slope angle $35^{0}$ with respect to the horizontal ground surface 
Sadaq and Mehdi

Table 1(a): Consolidate results of amount of water collected w.r.t time and date at slope angle $35^{\circ}$ with respect to the horizontal ground surface

\begin{tabular}{lllllll}
\hline Time & Feb 15 & Feb 28 & Mar 15 & Mar 30 & Apr 15 & Apr 30 \\
\hline $10 \mathrm{am}(\mathrm{ml})$ & 5 & 25 & 15 & 35 & 25 & 15 \\
$11 \mathrm{am}(\mathrm{ml})$ & 30 & 145 & 125 & 155 & 100 & 100 \\
$12 \mathrm{pm}(\mathrm{ml})$ & 95 & 285 & 255 & 280 & 150 & 150 \\
$1 \mathrm{pm}(\mathrm{ml})$ & 235 & 340 & 365 & 485 & 200 & 165 \\
$2 \mathrm{pm}(\mathrm{ml})$ & 400 & 435 & 495 & 550 & 150 & 190 \\
$3 \mathrm{pm}(\mathrm{ml})$ & 450 & 390 & 440 & 540 & 160 & 180 \\
$4 \mathrm{pm}(\mathrm{ml})$ & 350 & 365 & 350 & 510 & 170 & 190 \\
Total $(\mathrm{ml})$ & 1585 & 1985 & 2045 & 2555 & 955 & 990 \\
\hline
\end{tabular}

Table 1(b) Consolidate results of amount of water collected w.r.t time and date at slope angle $35^{\circ}$ with respect to the horizontal ground surface

\begin{tabular}{lllll}
\hline Time & May 15 & May 30 & Jun15 & Jun 30 \\
\hline $10 \mathrm{am}(\mathrm{ml})$ & 5 & 15 & 25 & 35 \\
$11 \mathrm{am}(\mathrm{ml})$ & 25 & 60 & 90 & 160 \\
$12 \mathrm{pm}(\mathrm{ml})$ & 65 & 125 & 185 & 235 \\
$1 \mathrm{pm}(\mathrm{ml})$ & 135 & 180 & 265 & 345 \\
$2 \mathrm{pm}(\mathrm{ml})$ & 175 & 235 & 350 & 375 \\
$3 \mathrm{pm}(\mathrm{ml})$ & 195 & 290 & 340 & 340 \\
$4 \mathrm{pm}(\mathrm{ml})$ & 140 & 280 & 350 & 370 \\
Total $(\mathrm{ml})$ & 740 & 1185 & 1605 & 1860 \\
\hline
\end{tabular}

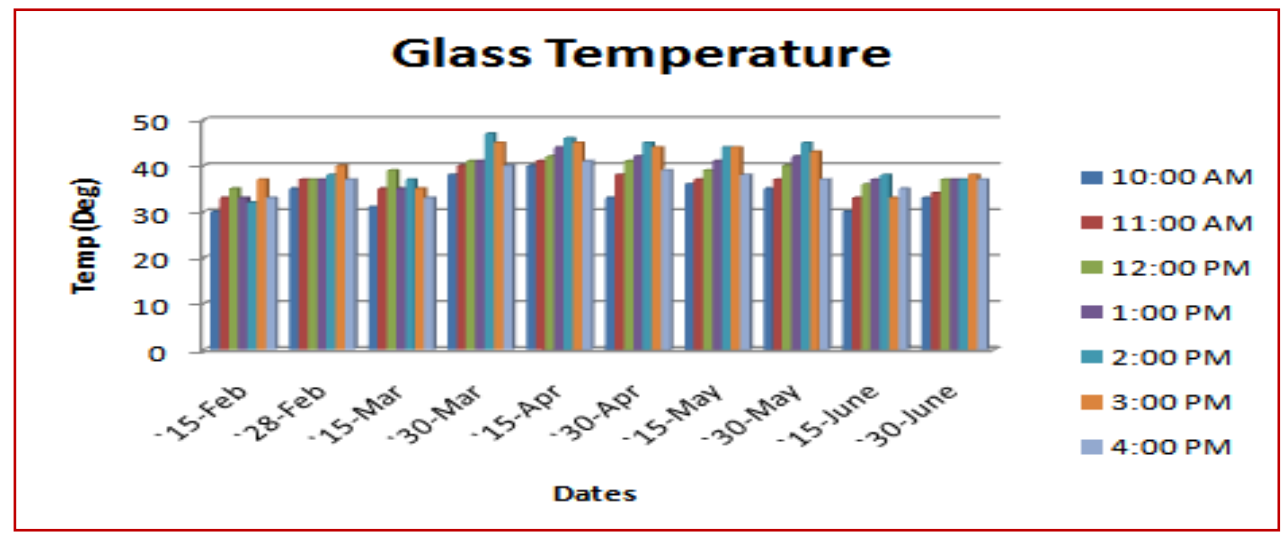

Figure 15 Graph represents the condensed glass temperature at different time interval on different days with slope angle $30^{\circ}$ with respect to the horizontal ground surface

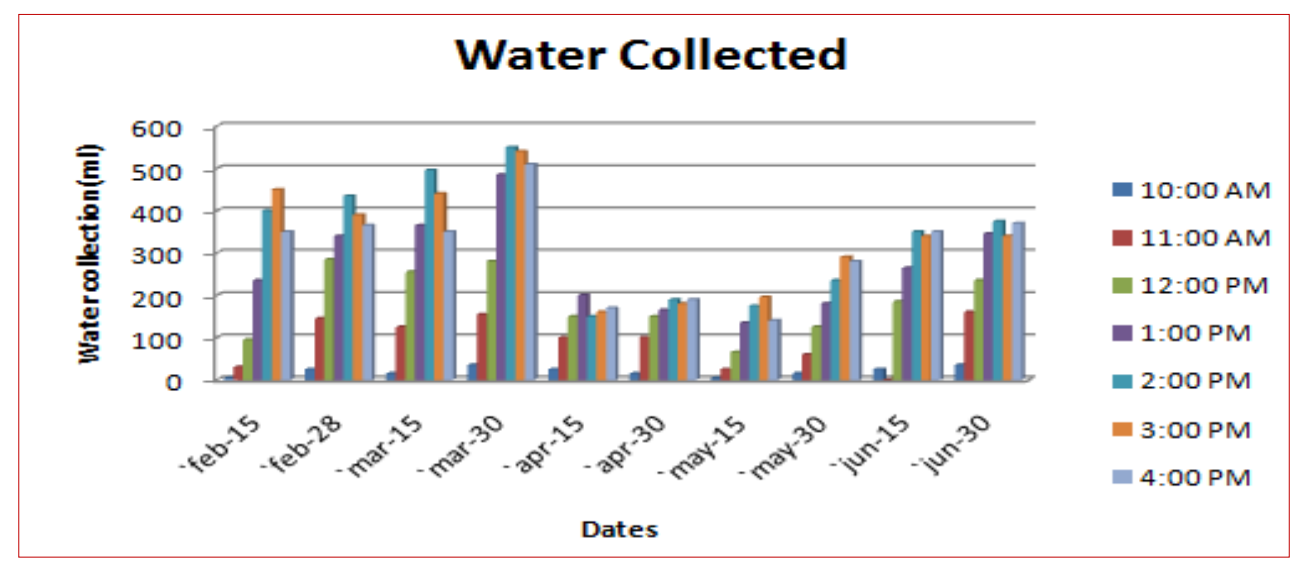

Figure 16 Graph represents the amount of water collected from outlet pipe at different time interval on different dates in $(\mathrm{ml})$ with slope angle $35^{\circ}$ with respect to the horizontal ground surface 178 


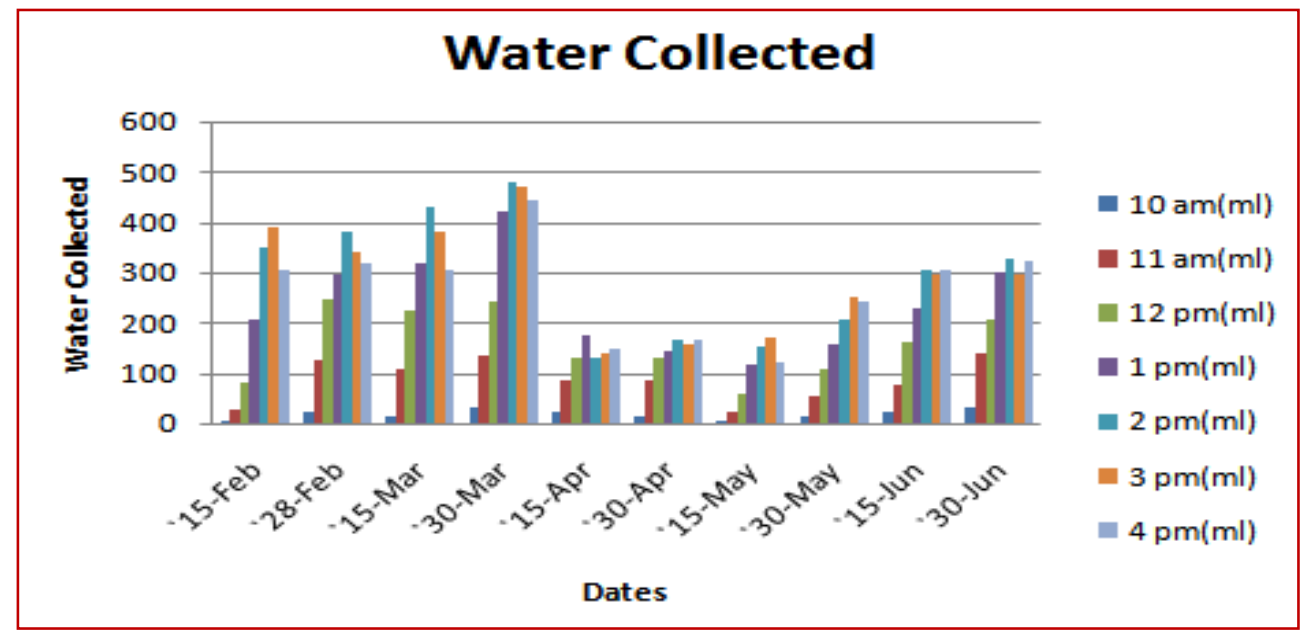

Figure 17 Graph represents the amount of water collected from outlet pipe at different time interval on different dates in (ml) with slope angle $30^{\circ}$ with respect to the horizontal ground surface

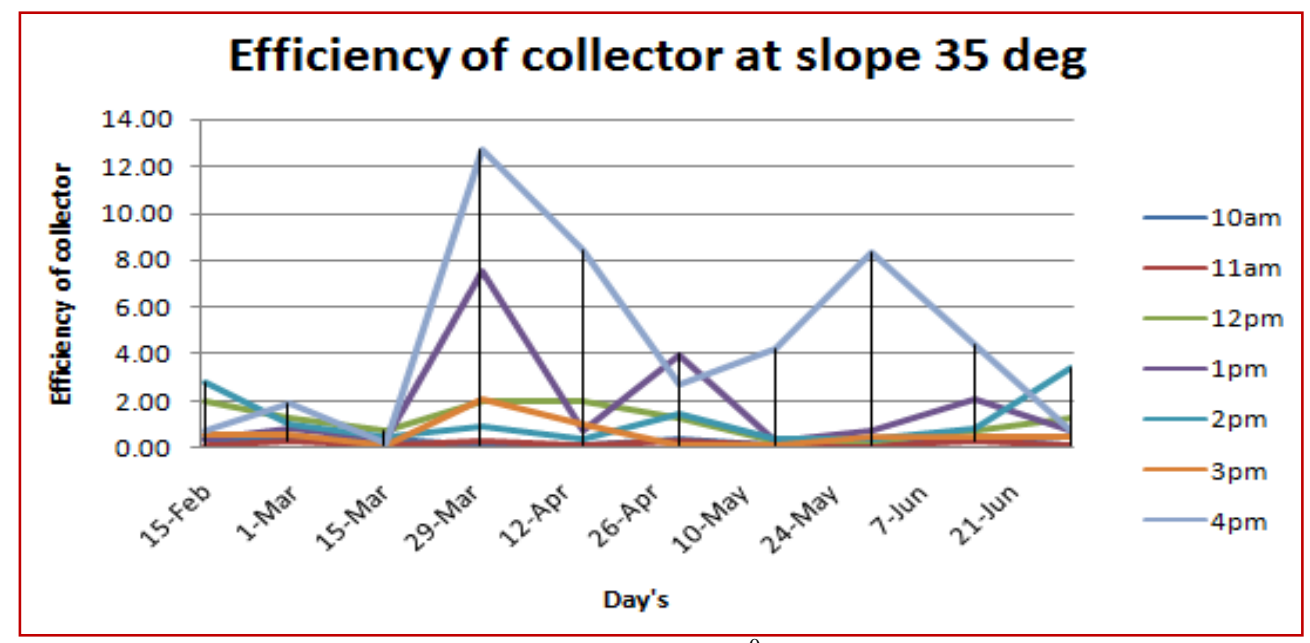

Figure 18 Efficiency of SDU / still at slope angle $35^{\circ}$ with respect to the horizontal ground surface

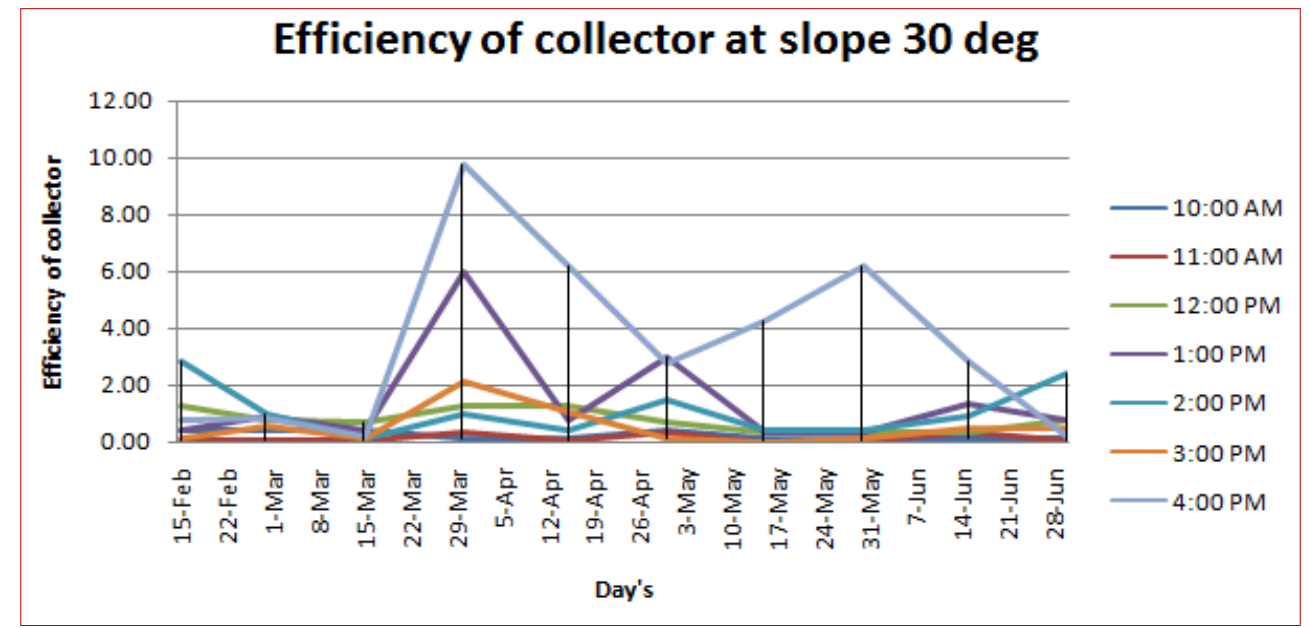

Figure 19 Efficiency of SDU / still at slope angle $30^{\circ}$ with respect to the horizontal ground surface 


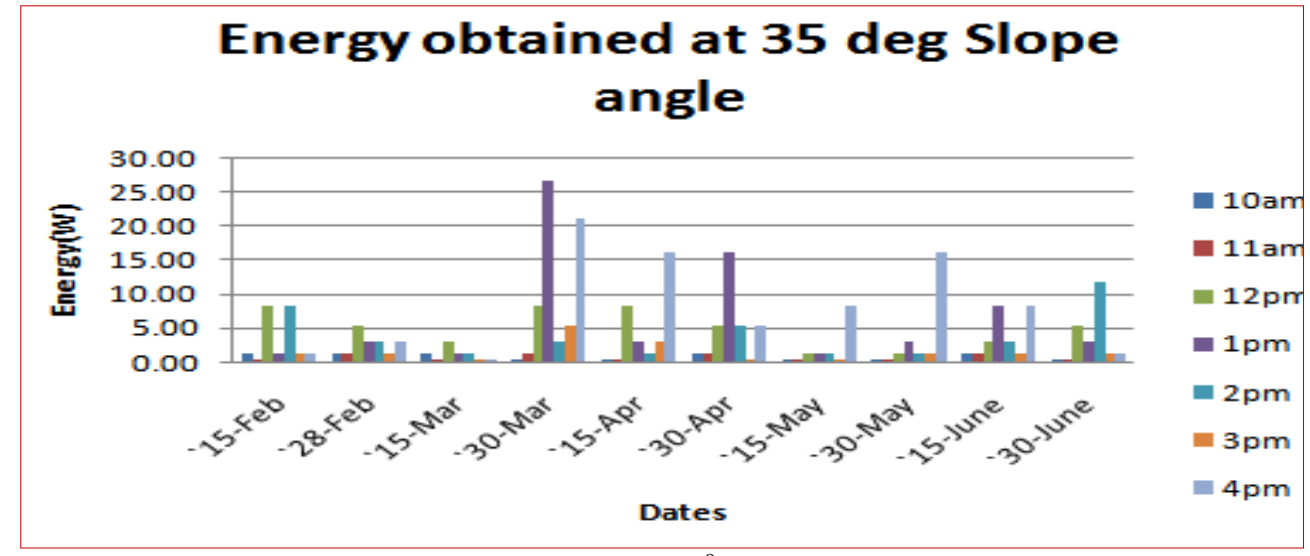

Figure 20 Energy of SDU / still at slope angle $35^{0}$ with respect to the horizontal ground surface

\section{Conclusion and future work}

It has been observed that evaporated water temperature are higher from 10:00am to 4:00pm with the slope angle $35^{\circ}$ and is maximum i.e. $54^{\circ} \mathrm{C}$ at $3: 00 \mathrm{pm}$ in the month of march on $30^{\text {th }}$ and $53^{\circ} \mathrm{C}$ at 3:00pm on April $15^{\text {th }}$, when compared with the same setup with slope angle of $30^{\circ}$ on the same days and same time. The variation of evaporated temperature between the angles is observed to be $13 \%$.

The glass and container temperature (i.e. Al sheet temperature) are higher from 10:00am to $4: 00 \mathrm{pm}$ with slope angle of $35^{\circ}$, and is maximum i.e. $56^{\circ} \mathrm{C}$ at $3: 00 \mathrm{pm}$ in the month of March $30^{\text {th }}$ and $54^{\circ} \mathrm{C}$ at 3:00pm on April 15 $5^{\text {th }}$, when compared with the slope angle of $30^{\circ}$. The variation of glass and container temperature between the slope angles is observed to be $12.5 \%$.

Radiations were calculated from Feb 15 to June 30 using solar calculations keeping slope angle constant, and considering latitude as 17.38 and longitude as 78.48 .

Hot Water temperature at slope angle $35^{\circ}$ is $57^{\circ} \mathrm{C}$ which is higher at $3: 00 \mathrm{pm}$ and $56^{\circ} \mathrm{C}$ at $4: 00 \mathrm{pm}$ on $30^{\text {th }}$ march and $56^{\circ} \mathrm{C}$ at $2: 00 \mathrm{pm}$ on $30^{\text {th }}$ April. When setup is made with slope angle $35^{\circ} \mathrm{C}$, compared to slope angle $30^{\circ} \mathrm{C}$. The variation between the slope angles is observed to be $12.28 \%$.

Maximum amount of water collected from $0.37 \mathrm{~m}^{2}$ area of solar distillation unit is $2555 \mathrm{ml}$ liters on 30 March for and corresponding glass temperature and water temperature is $327 \mathrm{k}$ and $330 \mathrm{k}$ with a slope of $35^{\circ}$, which is $13 \%$ more compared which the same solar distillation unit have same area with $30^{\circ}$ slope angle.
Maximum energy obtained from the setup with the slope angle $35^{\circ}$ is $21 \%$ more i.e. 26.50 watts which is significantly more when compare on same particular day with slope angle $30^{\circ}$.

Efficiency of the collector is $23 \%$ high i.e. $12.72 \%$ on $30^{\text {th }}$ march with slope angle $35^{\circ}$ and $9.74 \%$ on the same day with slope angle $30^{\circ}$. CFD analysis can be performed on the same SDU to validate the results obtained during experimentation. Aluminum contained can be replaced with copper container.

\section{Acknowledgment}

None.

\section{Conflicts of interest}

The authors have no conflicts of interest to declare.

\section{References}

[1] Velmurugan V, Srithar K. Performance analysis of solar stills based on various factors affecting the productivity-a review. Renewable and Sustainable Energy Reviews. 2011; 15(2):1294-304.

[2] Tiwari GN, Singh HN, Tripathi R. Present status of solar distillation. Solar Energy. 2003; 75(5):367-73.

[3] Badran OO, Abu-Khader MM. Evaluating thermal performance of a single slope solar still. Heat and Mass Transfer. 2007; 43(10):985-95.

[4] Abdallah S, Badran O, Abu-Khader MM. Performance evaluation of a modified design of a single slope solar still. Desalination. 2008; 219(1-3):222-30.

[5] Velmurugan V, Kumar KN, Haq TN, Srithar K. Performance analysis in stepped solar still for effluent desalination. Energy. 2009; 34(9):1179-86.

[6] Murugavel KK, Chockalingam KK, Srithar K. Progresses in improving the effectiveness of the single basin passive solar still. Desalination. 2008; 220(13):677-86.

[7] Gnanadason MK, Kumar PS, Sivaraman G, Daniel JE. Design and performance analysis of a modified 
vacuum single basin solar still. Smart Grid and Renewable Energy. 2011; 2(4):388.

[8] Gnanadason MK, Kumar PS, Wilson VH, Hariharan G, Vinayagamoorthi NS. Design and performance analysis of an innovative single basin solar NanoStill. Smart Grid and Renewable Energy. 2013; 4(1):88-98.

[9] Gokilavani NS, Prabhakaran DD, Kannadasan DT. Experimental studies and CFD modeling on solar distillation system. International Journal of Innovative Research in Science Engineering and Technology. 2014; 3(9): 15818-22.

[10] Panchal HN, Patel P, Mevada R, Patel H. Reviews on different energy absorbing materials for performance analysis of solar still. International Journal of Advance Engineering and Research Development. 2014; 1(11):62-6.

[11] Shakaib M, Khan MA. Modeling of fluid flow and temperature profiles in solar stills using CFD. Proceedings of international conference on chemical, metallurgy and environmental engineering 2015.

[12] Amraoui MA. Numerical Study of the Threedimensional Flow in a solar collector flat plate with baffles. S01 Advanced Modeling In Mechanics of Solids and Fluids. 2015.

[13] Reddy P, Prasad CR, Varma BH. CFD Analysis of single basin double slope solar still.2016.
[14] Shehabuddeen K, Katyiemb HHAl, Mazhanash H. Efficient water recycling through solar distillation. Journal of Advanced Research in Fluid Mechanics and Thermal Sciences. 2015; 15(1):17-27.

[15] Ali MI, Joseph B, Karthikeyan R, Yuvaraj R. Performance investigation of solar still integrated to solar pond. Bonfring International Journal of Power Systems and Integrated Circuits. 2012; 2(1):1-7.

[16] Afrand M, Kalbasi R, Karimipour A, Wongwises S. Experimental investigation on a thermal model for a basin solar still with an external reflector. Energies. 2016; 10(1):1-16.

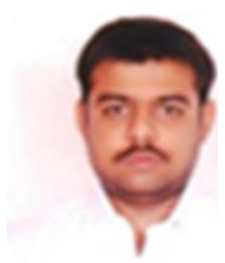

S. Irfan Sadaq, born in 1987. He received his bachelor degree in Mechanical Engineering from JNTUH and Master Degree Mechanical Engineering (CAD/CAM) from Osmania University in 2010. At present, he is pursuing $\mathrm{Ph} . \mathrm{D}$ degree in Mechanical Engineering, Mewar University, Rajasthan, India. He published more than 20 articles in various International journals of mechanical engineering. He is working as Assistant Professor in Department of Mechanical Engineering, Muffakham Jah College of Engineering \& Technology, Hyderabad, Telangana, India.

Email: irfan.sadaq@mjcollege.ac.in 